Article

\title{
Clonal Behavior in Response to Soil Water Availability in Tempranillo Grapevine cv: From Plant Growth to Water Use Efficiency
}

\author{
Ignacio Tortosa $^{1}$, Jose M. Escalona ${ }^{1,2}$, , Guillermo Toro $^{3 \oplus}$, Cyril Douthe ${ }^{1}$ \\ and Hipolito Medrano ${ }^{1,2, *}$ \\ 1 Agro-Environmental and Water Economics Institute (INAGEA-UIB), cta. de Valldemossa Km 7.5, \\ 07122 Palma de Mallorca, Spain; i.tortosa@uib.es (I.T.); jose.escalona@uib.es (J.M.E.); \\ douthecyril@gmail.com (C.D.) \\ 2 Research Group on Plant Biology Under Mediterranean Conditions, Department of Biology, \\ Universitat de les Illes Balears, cta. de Valldemossa Km 7.5, 07122 Palma de Mallorca, Spain \\ 3 Centro de Estudios Avanzados en Fruticultura (CEAF), Camino Las Parcelas 882, km 105 Ruta Sur, \\ Sector los Choapinos, Rengo 2940000, Chile; gtoro@ceaf.cl \\ * Correspondence: hipolito.medrano@uib.es
}

Received: 20 May 2020; Accepted: 16 June 2020; Published: 18 June 2020

\begin{abstract}
Climate change threatens worldwide grapevine production, especially in Mediterranean areas. To assume this challenge, the replacement of plant material to choose one more adapted to the new environmental conditions has been proposed as one of the possible solutions. Thus, the study of genetic variability in water-use efficiency (WUE) is needed to guarantee the survival of viticulture in those critical areas. In this study, the variability of WUE in 23 Tempranillo clones growth in pots and submitted to well-watered conditions and moderate water stress was studied along two consecutive years. Leaf net photosynthesis (AN), stomatal conductance $\left(\mathrm{g}_{\mathrm{s}}\right)$, and plant growth parameters were measured, in addition the instrisic WUE $\left(\mathrm{AN} / \mathrm{g}_{\mathrm{s}}\right)$, biomass production, and water consumed were calculated. Results show a clear genotype effect for most of the studied parameters, but, with an important year by year variability. We identified different clonal behavior in response to soil water availability, that permits to classify them as water-savers vs water-spenders. In general, there was no found relationship between leaf and plant WUE, even some genotypes as 232 or 1048 were coincident in higher leaf WUE showed highly productive in terms of biomass accumulation per unit of water applied.
\end{abstract}

Keywords: Vitis vinifera L.; photosynthesis; biomass; climate change; sustainability; clonal selection

\section{Introduction}

Climate change (CC) is one of the most important challenges for the future of viticulture in the Mediterranean area [1]. The already observed and expected increase in maximal temperatures, together with a general increase in high intensity rain events, can turn viticulture even to a difficult crop in most of the semiarid regions. To face these consequences, different options are already in use like moving to a higher altitude or increasing the irrigation dependency [2]. Another way to deal with adverse weather conditions is the replacement of plant material to choose one more adapted to the new environmental conditions [3]. This could also result in a more sustainable vineyard in terms of water management. Vine genetic variability is an invaluable resource that offers a panel of cultivars with a potential higher drought or heat tolerance $[4,5]$.

The specificity of the wine market is that each wine label is usually linked to a specific territory. For this reason, different protection figures in most of the viticulture areas prevent the substitution 
of traditional cultivars by others. In Spain, Tempranillo is the most extended red cultivar in any wine region along the country. The wide geographical distribution of Tempranillo cv confer it a high intra-cultivar variability, which is represented by up to 50 commercial clonal lines available for winemakers. The variability inside one cultivar is a promising way to maintain wine sustainability in the near future [6]. Therefore, we have planned to explore the inherent variability of the Tempranillo cultivars in order to select clones with improved water use efficiency (WUE).

WUE is commonly accepted as reliable criteria to evaluate the water dependency of one genotype, cultivar or clone, referred principally to water productivity (production per unit of water used). Such WUE can be measured at different evaluation scales like the plant production in terms of biomass or crop production per unit of water applied (whole plant WUE; $\mathrm{WUE}_{\mathrm{wp}}$ ); or at the leaf scale, evaluating the net carbon gain $\left(\mathrm{A}_{\mathrm{N}}\right)$ per water transpired or more specifically per unit of stomatal conductance $\left(\mathrm{g}_{\mathrm{s}}\right)$ (intrinsic $\mathrm{WUE} ; \mathrm{WUE}_{\mathrm{i}}$ ), as well as per surrogate characters as the $\delta^{13} \mathrm{C}$ discrimination [7-9]. However, the correspondence between the estimated WUE at the different scales shows a variable agreement [10]. To explain such discrepancies, different unmeasured water or carbon losses are claimed as the night respiration and transpiration, the canopy light interception, and the roots carbon losses [11-13]. At whole plant scale, a reduction in irrigation regime could lead to a certain reduction of plant growth, which, in turns could be affecting the $W_{U E}$. Instead, a moderate reduction in leaf $g_{s}$ generally allows maintenance of a considerable $A_{N}$ rate, reaching the highest $W_{U} E_{i}[14-16]$.

Despite these apparent differences between measuring scales, the genetic variability in terms of WUE has been widely studied within grapevine cultivars. Several authors [17-19] have reported WUE variability in different assays under controlled conditions among cultivars at both scales leaf and whole plant, and also under field experiment [20]. In conclusion, comparative measurements of leaf gas exchange parameters seem a promising way to characterize genotype WUE both under pot and field conditions allowing to rank plant material by WUE [21].

Clonal variability was early used by commercial nurseries to obtain new certified material resistant to face fungal or bacterial infection, or differentiated by production or quality $[6,22,23]$. Nowadays, there is an increasing interest to show the performance of some clones under simulated climatic change conditions [24], as well as to establish large clone collections to conserve the intra-cultivar variability and to use molecular markers to identify clonal differences $[25,26]$.

Because the wine industry rules make difficult the variety replacement, we, started to explore the existence of genetic variability for WUE among different clones of Tempranillo, showing that variability is as large as an $80 \%$ of intra-cultivar variability under field conditions [27]. In the same research line, we corroborate later that these differences between clones are maintained year by year by repeating WUE measurements in long time study in the field [28]. Experiments performed of those clones grown in pots showed certain differences compared to field conditions, but that allows more effective control in terms of water availability, reducing the effect of sources of variability and non-controlled interferences such different individual root extension or particular vegetative development conditions.

In the present work, we study the behavior of 23 Tempranillo clones submitted to different soil water availability. The experiment was carried out in pot conditions with water availability control, during two consecutive years measuring different parameters related with water status, plant growth, and gas exchange regulation in order to establish a provisional ranking of clones based on WUE at leaf scale and eventually to explore the capacity to select the ones with higher and lower WUE.

\section{Material and Methods}

\subsection{Plant Material}

The plant material used in this experiment includes 23 Tempranillo genotypes from two origins; a public collection of La Grajera (ICVV, Instituto de las Ciencias del Vino y la Viticultura) (Logroño, la Rioja, Spain), and a private collection of Bodegas Roda (Haro, La Rioja, Spain) (Table 1). These two sites of origin present an experimental field with a high number of Tempranillo genotypes. A first 
agronomic and genetic approach allowed to reduce the genotypes variability in a nuclear collection. The final selection of the genotypes used in the experiment was done from previous field physiological and agronomical measurements inside these nuclear collections in order to identify the more contrasting genotypes [25]. In addition, three reputed commercial clones were included in the experiment (RJ43, RJ51, and RJ78). All genotypes were grafted on 110R, the most common rootstock used in Spain.

Table 1. Plant material origin.

\begin{tabular}{cc}
\hline ICVV & Bodegas Roda \\
\hline RJ43 * & 108 \\
RJ51 * & 137 \\
RJ78 * & 156 \\
1048 & 166 \\
1052 & 178 \\
1078 & 203 \\
1084 & 215 \\
1371 & 232 \\
232 & 243 \\
326 & 336 \\
& 360 \\
& 365 \\
& 452 \\
\hline * Indicates commercial clones.
\end{tabular}

\subsection{Experimental Conditions}

\subsubsection{Growing Conditions and Treatments}

The experiment was carried out under field conditions at the University of Balearic Islands (Mallorca, Spain) during summer 2017 and 2018. In 2017, one-year-old plants (five replicates per genotype) were grown outdoor in 20-L pots filled with organic substrate and perlite mixture (4:1). Additionally, a geotextile irrigation blanket was used to minimize direct soil evaporation.

In the first year, vines were pruned to two shoots per plant, and second year study plants were pruned to three shoots and one bunch per shoot. In all cases, during the first growing stages, plants were irrigated at field capacity and fertilized once a week with Hoagland nutrient solution diluted in distilled water at $25 \%$. The irrigation system consisted in two drippers per plant with a $0.5 \mathrm{~L} \mathrm{~h}^{-1} \mathrm{flow}$ to avoid overflow.

Treatments started when the total plant stem reached $1.5 \mathrm{~m}$. First, the plants remained 10-15 days in well-watered (WW) condition that were followed by 5 days without irrigation. Then, the irrigation was reduced to around $60 \%$ respect well-watered period to maintain additionally the plants in moderate water stress (MWS) over 10 days.

\subsubsection{Climate Conditions}

The climate conditions of the two years of the measurements were as common for the Mediterranean area, with soft winters and hot and dry summers. Meteorological data were monitored using a weather station situated in the same experimental field (Meteo3000, Geonica). Mean temperature during spring ranged between 20 and $30^{\circ} \mathrm{C}, 2017$ being in general hotter than in 2018 . However, during July and August, this effect was compensated. The reference evapotranspiration $\left(\mathrm{ET}_{\mathrm{O}}\right)$ during the treatment periods were as mean between 4 and $5 \mathrm{~mm}_{\text {day }}{ }^{-1}$ the two experimental years, with maximum of 6.1 and $5.8 \mathrm{~mm} \mathrm{day}^{-1}$ (2017 and 2018, respectively) 


\subsection{Measurements}

\subsubsection{Plant Water Status}

The plant water status was monitored by measuring the midday stem water potential $\left(\Psi_{\text {stem }}\right)$ with a Scholander pressure chamber (Soil moisture Equipment Corp. Santa Barbara, CA, USA). The measurements were done several times along the experiment between 13 and $14 \mathrm{~h}$ (local time) in one healthy, sun exposed, and mature leaf per plant bagged with both plastic sheet and aluminum foil at least one $\mathrm{h}$ before measurement to prevent direct transpiration.

\subsubsection{Leaf Gas Exchange Measurements}

Leaf net photosynthesis $\left(A_{N}\right)$ and stomatal conductance $\left(g_{s}\right)$ were measured in fully exposed mature leaves (one per plant, $\mathrm{n}=5$ ) every 2-3 days. All measurements were done between 10:00 and 13:00 h (local time) using an infrared open gas exchange analyzer system (Li-6400xt, Li-cor Inc., Lincoln, Nebraska, USA). The $\mathrm{CO}_{2}$ concentration inside the chamber was $400 \mu \mathrm{mol} \mathrm{CO} \mathrm{Col}^{-1}$ air, and an air flow of $500 \mu \mathrm{mol}$ (air) $\mathrm{min}^{-1}$. The chamber used has an area of $6 \mathrm{~cm}^{2}$ exposed to environmental light radiation, with PAR always above $1500 \mu \mathrm{mol} \mathrm{m}{ }^{-2} \mathrm{~s}^{-1}$. Intrinsic water use efficiency $\left(\mathrm{WUE}_{\mathrm{i}}\right)$ was calculated as the ratio between $A_{N}$ and $g_{s}$.

The $g_{s}$ were used to control the irrigation management in each treatment, trying to maintain plants over $0.150 \mathrm{~mol} \mathrm{H}_{2} \mathrm{O} \mathrm{m}^{-2} \mathrm{~s}^{-1}$ for well-irrigated plants and between 0.150 and $0.075 \mathrm{~mol} \mathrm{H}_{2} \mathrm{O} \mathrm{m}^{-2}$ $\mathrm{s}^{-1}$ for moderate stress conditions (Medrano et al., 2012). $\Psi_{\text {stem }}$ was maintained as mean between -0.6 and -0.7 MPa during well-watered conditions and around -1.2 MPa under moderate stress (Figure 1).

All $W_{U} E_{i}$ data were studied according to the residual analysis of each genotype average in respect to the general regression curve following Tortosa et al. (2016). To compare the genotype performance both under WW and WS conditions, the average residuals of each particular genotype was represented in a two axis figure to show the particular relative position of each genotype both under WW and WS conditions.

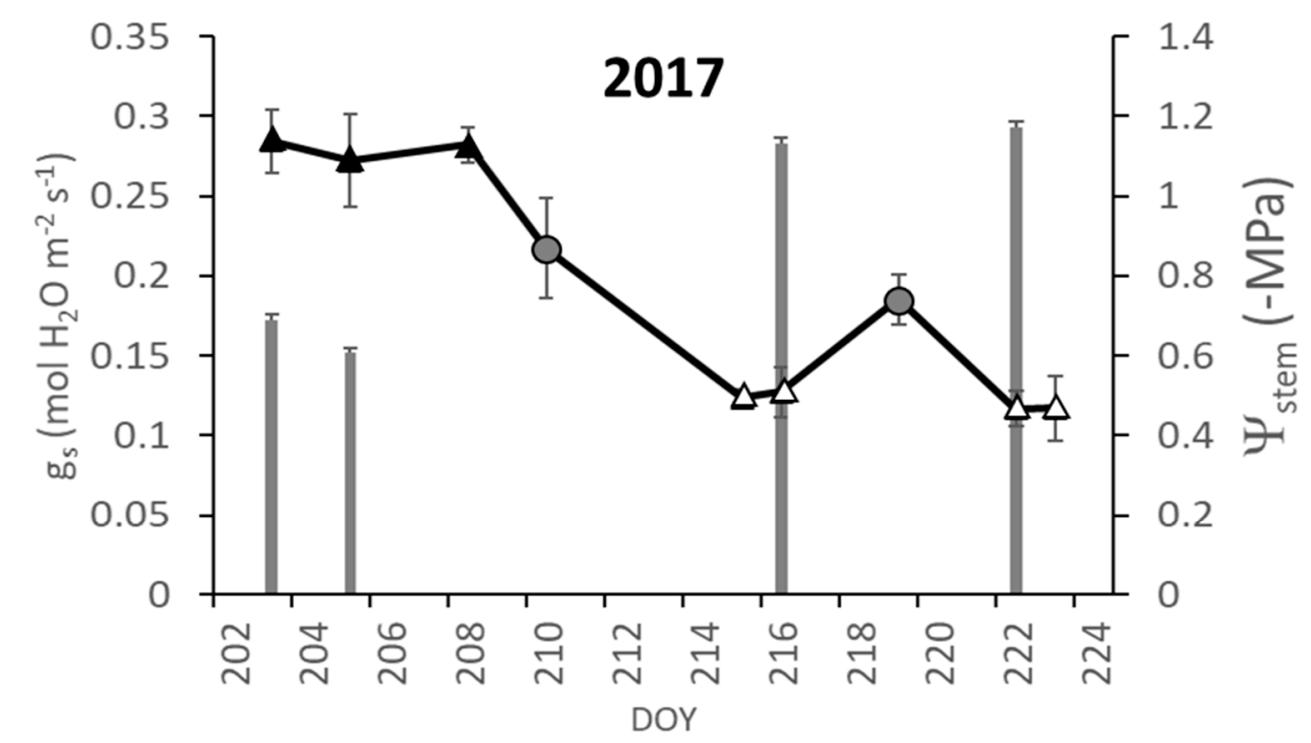

Figure 1. Cont. 


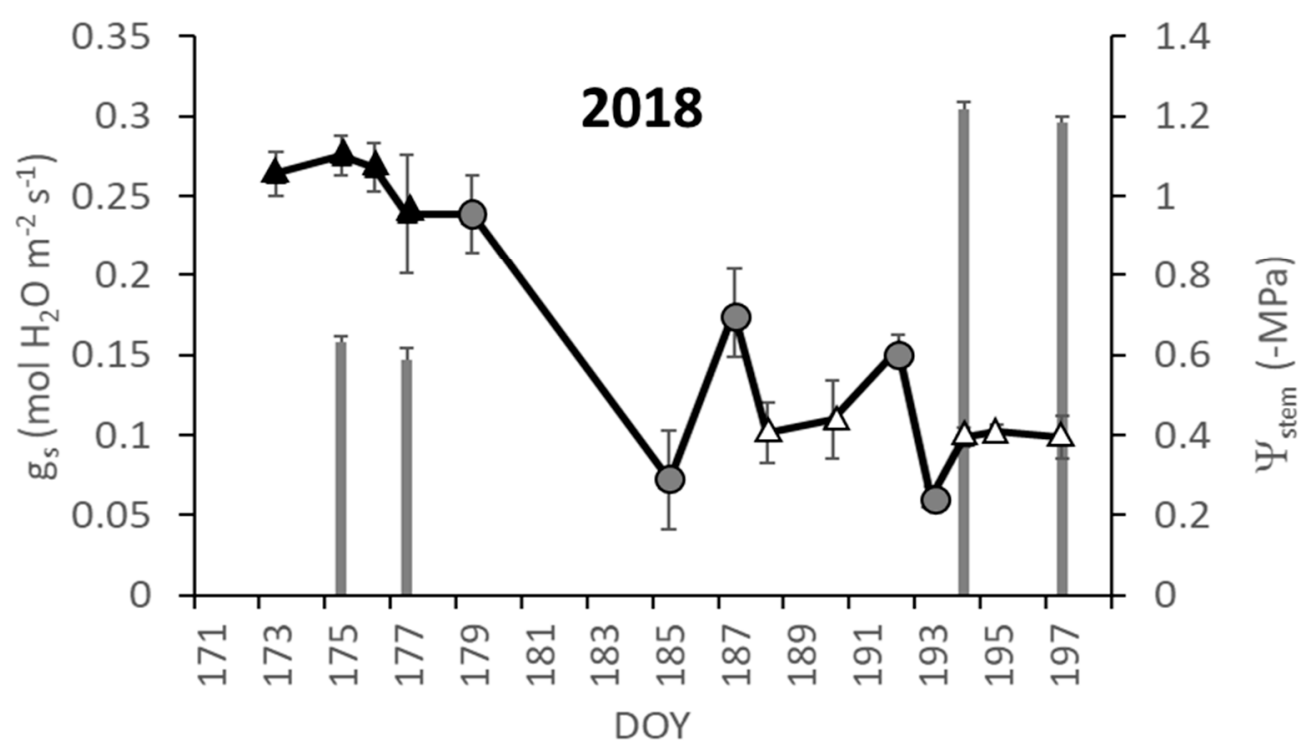

Figure 1. Plant water status during the 2017 and 2018 assays (all genotypes together). Lines and symbols represent the $g_{s}$ (left axis) and bars represent $\Psi_{\text {stem }}$ (right axis). Values are the mean of all measurements of the 23 genotypes per day and errors bars represent the standard error $(n=25-50)$. Black triangles represent a measure of well-watered (WW) status, white triangles a measure of moderate water stress (MWS), and grey circles a control of the plant water status.

\subsubsection{Plant Growth and Final Biomass}

Plant leaf number and shoot length were measured in all plants per genotype at the beginning and the end of each treatment period. Shoot length by the plant was the sum of the individual shoot of each plant. The plant growth was estimated using stem growth rate (SGR) and a leaf appearance rate (LAR) parameters obtained from leaf number and shoot length measurements. At the end of each experimental cycle (2017 and 2018), the aerial biomass was weighted. Leaf, shoot, and bunches dry weight per plant were determined separately.

The whole plant water use efficiency ( $\left(\mathrm{UE}_{\mathrm{wp}}\right.$ ) was calculated as a ratio between plant growth or plant biomass divided by water applied by irrigation. Because the irrigation amount was the same for all genotypes, the WUE $\mathrm{wp}_{\mathrm{wp}}$ was only dependent of the growth/biomass.

\subsection{Statistical Analysis}

All statistical analyses were performed using $R$ [29]. First, a global three-ways ANOVA was performed with Genotype $\times$ Years $\times$ Treatment as main effect and their interaction. The $W_{U E} E_{i}-g_{s}$ relationship was compared (ANCOVA from the "car" package [30] of different years and genotypes, using the cld analysis from the "emmeans" package [31]. Any differences were accepted with $p$-value $<0.05$.

\section{Results}

\subsection{Plant Growth}

Under well-watered condition, the stem growth rate (SGR) was considerably higher in the first year of study compared to the second year (Figure 2A,B), showing mean values of 4.4 and $2.2 \mathrm{~cm}^{\text {day }}{ }^{-1}$ respectively. The first year of study, the genotypes 215 and 232 showed the higher SGR (5.9 and $\left.5.6 \mathrm{~cm} \mathrm{day}^{-1}\right)$ and genotypes 336 and 1052 the lowest $\left(2.7\right.$ and $3.5 \mathrm{~cm} \mathrm{day}^{-1}$ ) (Figure 2A). In the second year of study, genotype 243 presented the highest SGR $\left(3.4 \mathrm{~cm}^{-1 a y^{-1}}\right.$ and $)$ against genotype 108 $\left(1.6 \mathrm{~cm} \mathrm{day}^{-1}\right)$ (Figure 2B). 

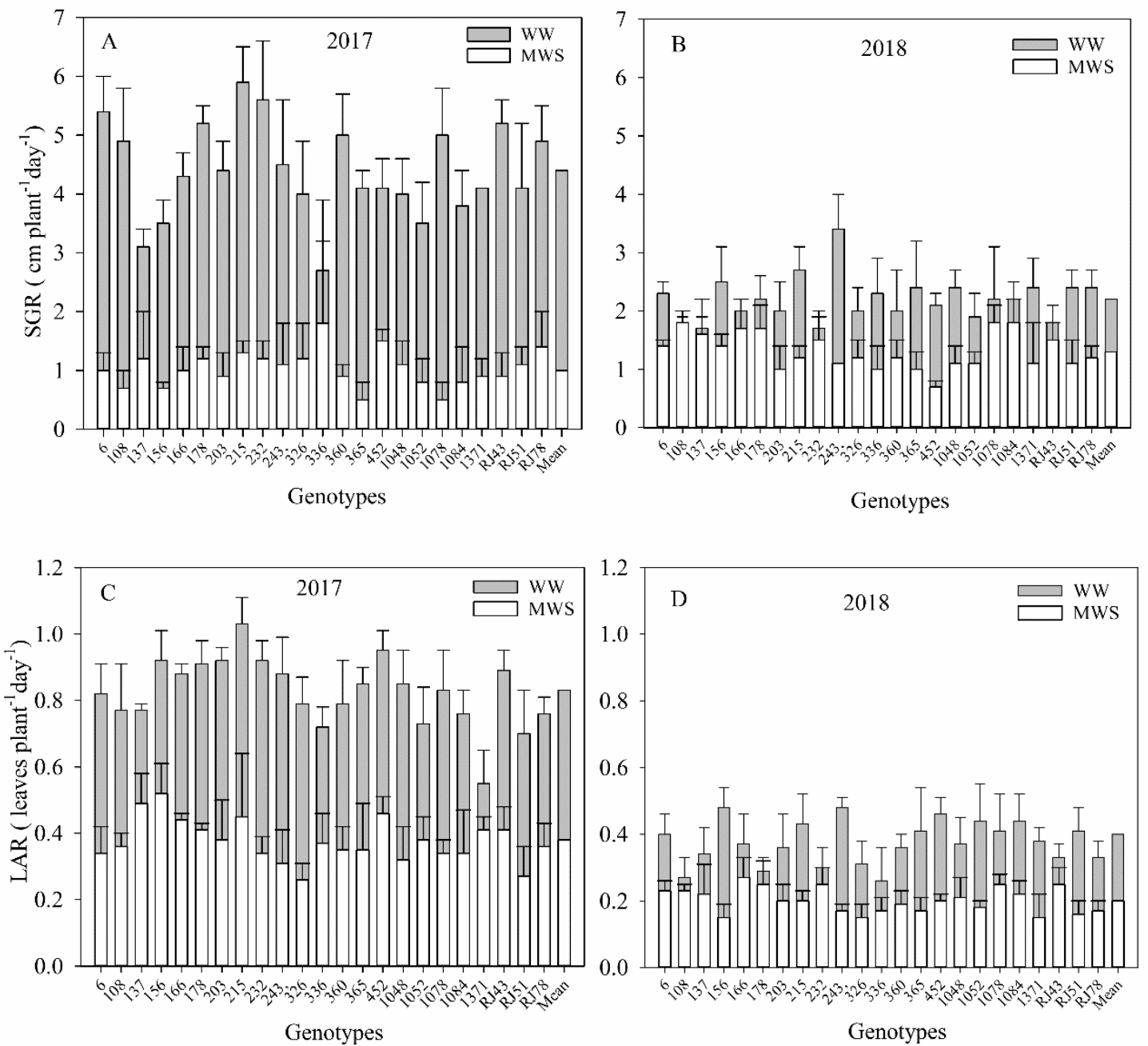

Figure 2. Stem growth rate (SGW) and leaf appearance rate (LAR) of each genotype measured in 2017 $(\mathbf{A}, \mathbf{C})$ and 2018 (B,D) in well-watered (WW) (grey bars) and moderate water stressed (MWS) (white bars) (White bars). Values are the mean $\pm \mathrm{SE}(\mathrm{N}=5)$.

Leaf appearance rate (LAR) also was similarly affected by the year as SGR. Under well-watered condition (WW), plants during 2017 showed a mean of LAR twice than during 2018 (Figure 2C,D). These differences between years were likely due to the presence of bunches in 2018 that implied a reduction in vegetative growth represented by the two studied parameters. In 2017, genotype 215 showed higher LAR than RJ51 (1.03 leaf day ${ }^{-1}$ and 0.55 leaf day $^{-1}$, respectively). In 2018, genotype 243 had the higher LAR and genotype 108 the lowest LAR ( 0.48 and 0.27 leaf day $^{-1}$ respectively).

In both years, moderate water stress (MWS) significantly reduced SGR ranged between 25 and 90\% (Figure 2A,B). This reduction was in general higher during 2017, likely due to a higher SGR. MWS condition also affected LAR, showing a reduction between 54 and $44 \%$ respect to WW condition for 2017 and 2018, respectively. Under this condition, the variability between genotypes in both parameters was lower than under WW condition, especially during 2018. Then, in 2017, the genotype 452 showed the higher SGR and LAR, $\left(1.5 \mathrm{~cm} \mathrm{day}^{-1}\right.$ and 0.46 leaf day ${ }^{-1}$ respectively $)$, and the genotype 1078 showed the lowest values of these two parameters $\left(0.5 \mathrm{~cm} \mathrm{day}^{-1}\right.$ and 0.34 leaf day ${ }^{-1}$, respectively). On the contrary, during 2018, genotype 452 presented the lowest SGR $\left(0.7 \mathrm{~cm} \mathrm{day}^{-1}\right)$ and genotype 1078 the highest $\left(1.8 \mathrm{~cm} \mathrm{day}^{-1}\right)$.

Statistical analysis showed that the genotype effect was significant for the LAR $(p<0.05)$, but not for SGR considering both years of study (Table 2). 
Table 2. Three-Ways ANOVA performed for genotype $\times$ years $\times$ treatment as main effect on growth, biomass, and gas exchange parameters, and their interaction.

\begin{tabular}{|c|c|c|c|c|c|c|c|c|c|}
\hline \multirow{2}{*}{ Effects } & \multicolumn{2}{|c|}{ Growth } & \multicolumn{4}{|c|}{ Biomass } & \multicolumn{3}{|c|}{ Gas Exchange } \\
\hline & SGR & LAR & Leaves & Shoots & Bunches & Total & Gs & A & WUEi \\
\hline Genotype (Gen) & & * & $* * *$ & $* * *$ & & * & $* * *$ & $*$ & \\
\hline Year & $* * *$ & $* * *$ & ** & $* * *$ & - & $* * *$ & & & $* *$ \\
\hline Trat & $* * *$ & $* * *$ & - & - & - & & $* * *$ & $* * *$ & $* * *$ \\
\hline Gen $\times$ year & & & $* *$ & & - & - & & & \\
\hline Gen $\times$ Treat & & & - & - & - & . & & & \\
\hline Year $\times$ Treat & $* * *$ & $* * *$ & - & - & - & . & $* * *$ & $* * *$ & $* * *$ \\
\hline Gen $\times$ Year $\times$ Treat & * & & - & - & - & . & & & \\
\hline
\end{tabular}

\subsection{Final Biomass}

Figure 3 shows the final biomass of the aerial parts of the plant for each genotype. In 2017, dry biomass was distributed almost equally in leaf and stem factions, showing mean values of 38.3 and $40.4 \mathrm{~g}$ in leaf and stem respectively (Figure 3A). In 2018, the bunches weights supposed about $25 \%$ of total dry weight (Figure 3B). In this year, total plant dry matter was higher than in 2017 (94.5 and $78.7 \mathrm{~g}$, respectively), mainly because the presence of bunches induced a change in the dry matter distribution among the different aerial parts of the plants.

The total stem dry biomass showed a wide range, ranged between 20 and $45 \mathrm{~g}$ per plant (Figure 3). In 2017, genotypes showed higher stem biomass, highlighting the genotypes 232, 1048, and 326, which showed values around $45 \mathrm{~g}$, in comparison to genotype RJ78 with a total stem weight of $30 \mathrm{~g}$ (Figure $3 \mathrm{~A}$ ). In the second year of study, genotype RJ51 had higher stem biomass ( $35 \mathrm{~g})$ in contrast with genotypes RJ43 and 215 (21g) (Figure 3B).

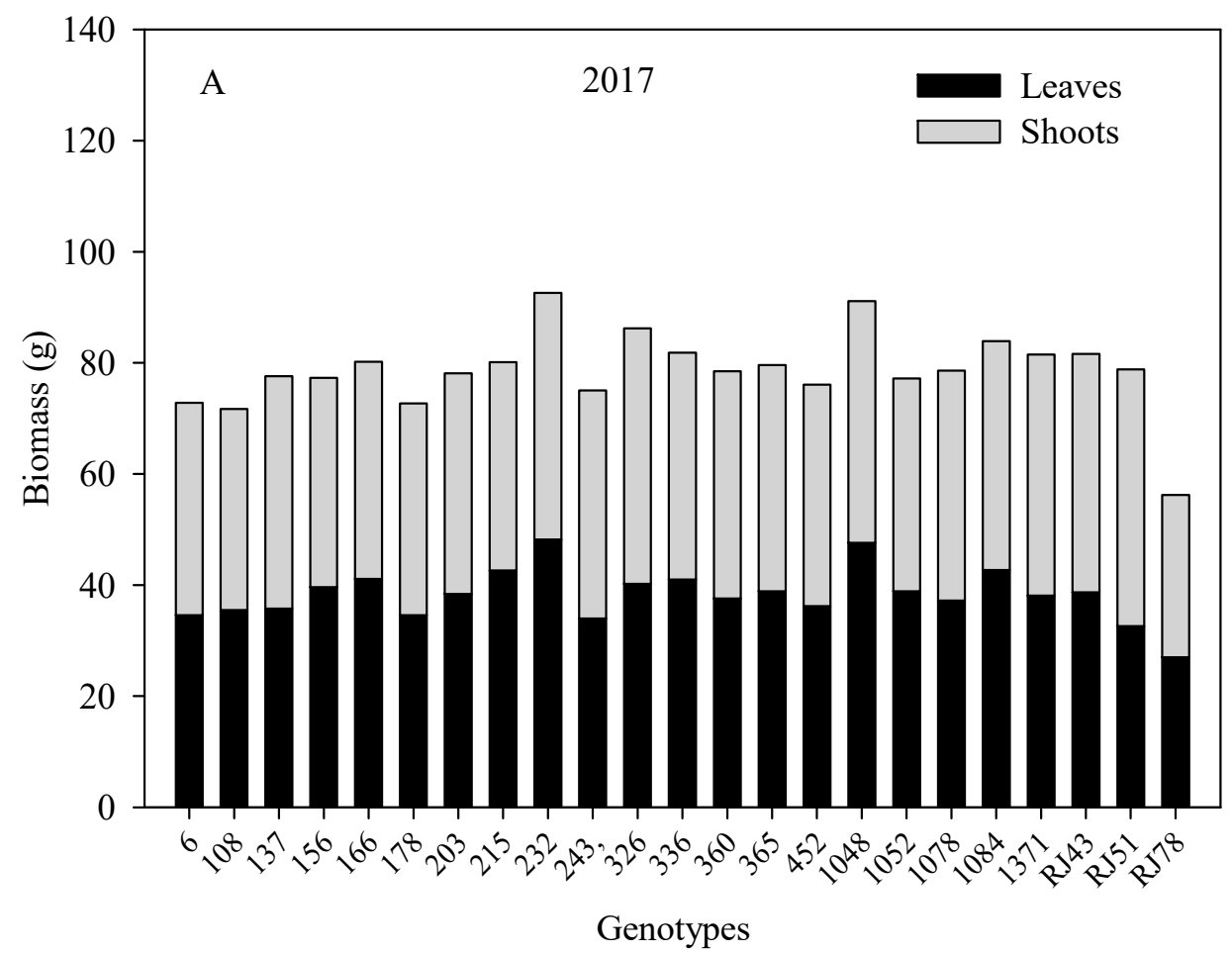

Figure 3. Cont. 


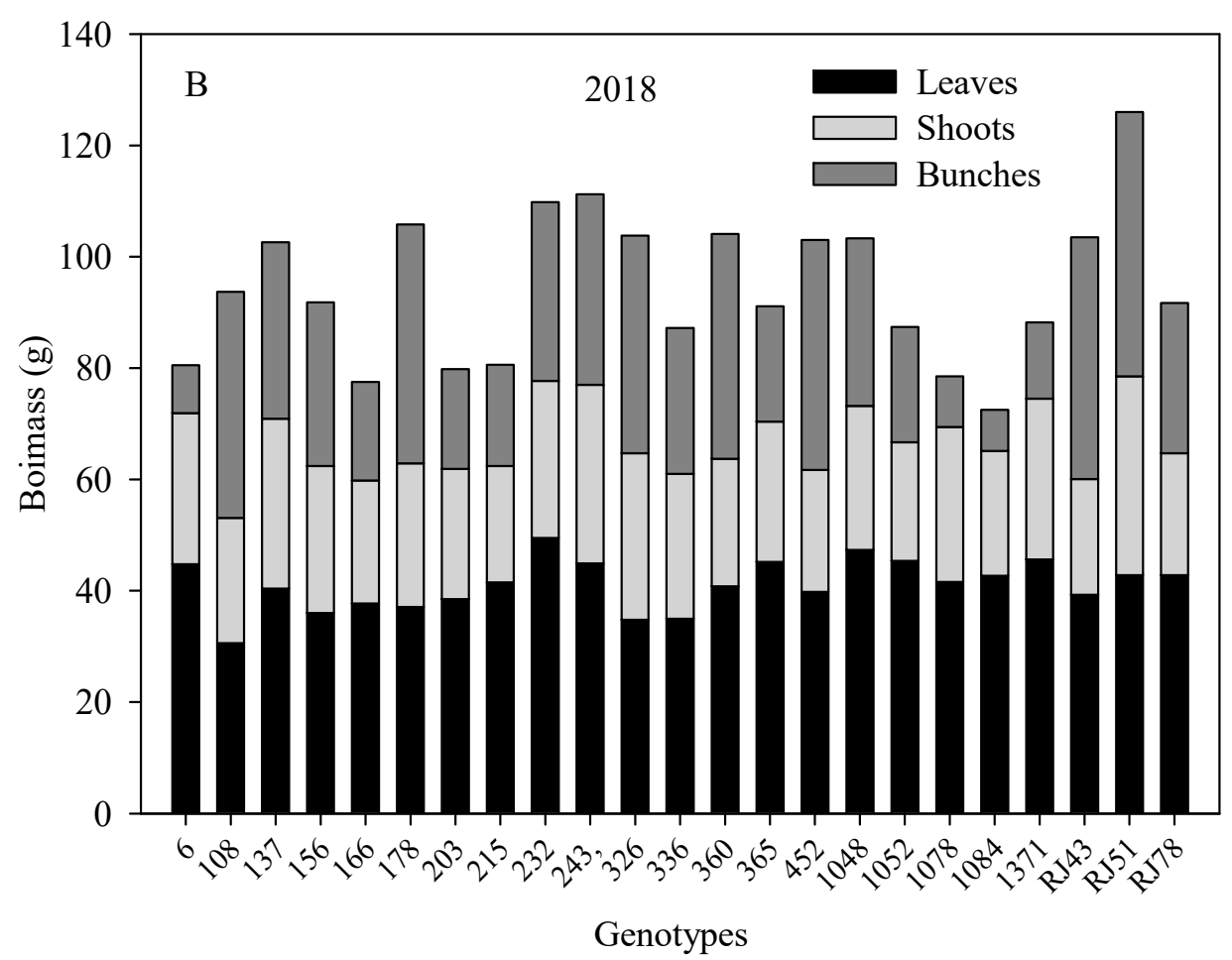

Figure 3. Total dry biomass divided in leaves (black bars), shoots (grey bars) and bunches (dark bars) measured at the end of experiments in 2017 (A) and 2018 (B) for each genotype $(\mathrm{N}=5)$.

The bunches weight presented large variations between genotypes (Figure 3B), ranged from 40 $\mathrm{g}$ in the genotypes RJ51, RJ43, and 178 to $10 \mathrm{~g}$ in the genotypes 6, 1078, and 1084. The total leaf dry weight varied between genotypes and years (Figure 3), and the two most productive genotypes were conserved during both years (232 and 1048, respectively). The total aerial dry biomass varied between 55 and $110 \mathrm{~g}$.

During the season 2017, genotypes more productive in terms of total biomass were 232 and 1048 with a production upper than $90 \mathrm{~g}$ in contrast with genotype RJ78 (56 g). In the second season (2018), the genotype RJ51 was the most productive (126 g) in contrast with genotype 166 (78 g). In general, there was no clear relationship between years in terms of total biomass production. However, some high productivity genotypes (232 and 326) showed high biomass production both years. Two-way ANOVA (Year $\times$ Genotype) showed genotype and the year effect significative for the total dry biomass, and for stem and leaf weight. Bunches weight effect were not significant (Table 2) and the interaction between year and genotype effects were significant only for leaves weight ( $p$-value $<0.01)$.

\subsection{Stomatal Conductance, Photosynthesis, and WUE $E_{i}$}

The means of stomatal conductance, photosynthesis, and $\mathrm{WUE}_{\mathrm{i}}$ are presented separated by years in the Figure 4 . The water stress treatment reduced $g_{s}$ by about $65 \%$ as mean (Figure $4 A, B$ ). This reduction in $\mathrm{g}_{\mathrm{s}}$ was accompanied to a reduction of $\mathrm{A}_{\mathrm{N}}$, from $13.6 \mu \mathrm{mol} \mathrm{m} \mathrm{m}^{-2} \mathrm{~s}^{-2}$ in well-watered (WW) to 7.8 in moderate water stress (MWS) (reduction of 57\%). The higher impact of water stress in $\mathrm{g}_{\mathrm{s}}$ compared to $\mathrm{A}_{\mathrm{N}}$ implied an increment on $\mathrm{WUE}_{\mathrm{i}}$, which ranged between 55 to $87 \mu \mathrm{mol} \mathrm{mol}^{-1}$.

The genotype effect was significative in $\mathrm{g}_{\mathrm{s}}(p$ value $<0.001)$, and in $\mathrm{A}_{\mathrm{N}}(p$-value $<0.05)$ and was not significative in $W_{U E}(p$-value $<0.1)$. For both years, the maximal $g_{s}$ in $W W$ was around $0.32 \mathrm{~mol}$ $\mathrm{H}_{2} \mathrm{O} \mathrm{m}^{-2} \mathrm{~s}^{-1}$ and the minimal $0.21 \mathrm{~mol} \mathrm{H}_{2} \mathrm{O} \mathrm{m}^{-2} \mathrm{~s}^{-1}$ (Figure 4A,B). These differences were also clear in $\mathrm{A}_{\mathrm{N}}$ and $\mathrm{WUE}_{\mathrm{i}}$ (Figure $4 \mathrm{C}-\mathrm{F}$ ). For example, under WW condition, genotype RJ78 showed a higher $\mathrm{g}_{\mathrm{s}}$ and lower $\mathrm{WUE}_{\mathrm{i}}$ both years, with 48.8 and $50.6 \mu \mathrm{mol} \mathrm{CO} \mathrm{Col} \mathrm{H}_{2} \mathrm{O}^{-1}$, respectively. In contrast, genotype 1052 showed a low $\mathrm{g}_{\mathrm{s}}$ both years $\left(0.21\right.$ and $\left.0.24 \mathrm{~mol} \mathrm{H}_{2} \mathrm{O} \mathrm{m}^{-2} \mathrm{~s}^{-1}\right)$ and not a high $\mathrm{WUE}_{\mathrm{i}}$ 
(57 and $52 \mu \mathrm{mol} \mathrm{CO} \mathrm{Col} \mathrm{H}_{2} \mathrm{O}^{-1}$, respectively). Under MWS treatment, the variation of $\mathrm{WUE}_{\mathrm{i}}$ was around $20 \mu \mathrm{mol} \mathrm{CO} \mathrm{Col} \mathrm{H}_{2} \mathrm{O}^{-1}$, reaching first year study genotypes 1052 and 156 around $90 \mu \mathrm{mol}$ $\mathrm{CO}_{2} \mathrm{~mol} \mathrm{H}_{2} \mathrm{O}^{-1}$, and genotypes 1371 and 6 to $70 \mu \mathrm{mol} \mathrm{CO} \mathrm{mol}^{-1} \mathrm{H}_{2} \mathrm{O}$. The second year of study, genotypes 1048 and 232 had the maximal $\mathrm{WUE}_{\mathrm{i}}$ (around $100 \mu \mathrm{mol} \mathrm{CO} \mathrm{mol} \mathrm{H}_{2} \mathrm{O}^{-1}$ ) compared to other genotypes 336 and $243\left(80 \mu \mathrm{mol} \mathrm{CO} \mathrm{CO}_{2} \mathrm{~mol} \mathrm{H}_{2} \mathrm{O}^{-1}\right)$. Against, the $\mathrm{g}_{\mathrm{s}}$ level that arises each genotypes highly conditioned the resultant $\mathrm{WUE}_{\mathrm{i}}$. In this water status treatment, values between years were poorly conserved (Figure 4E,F).
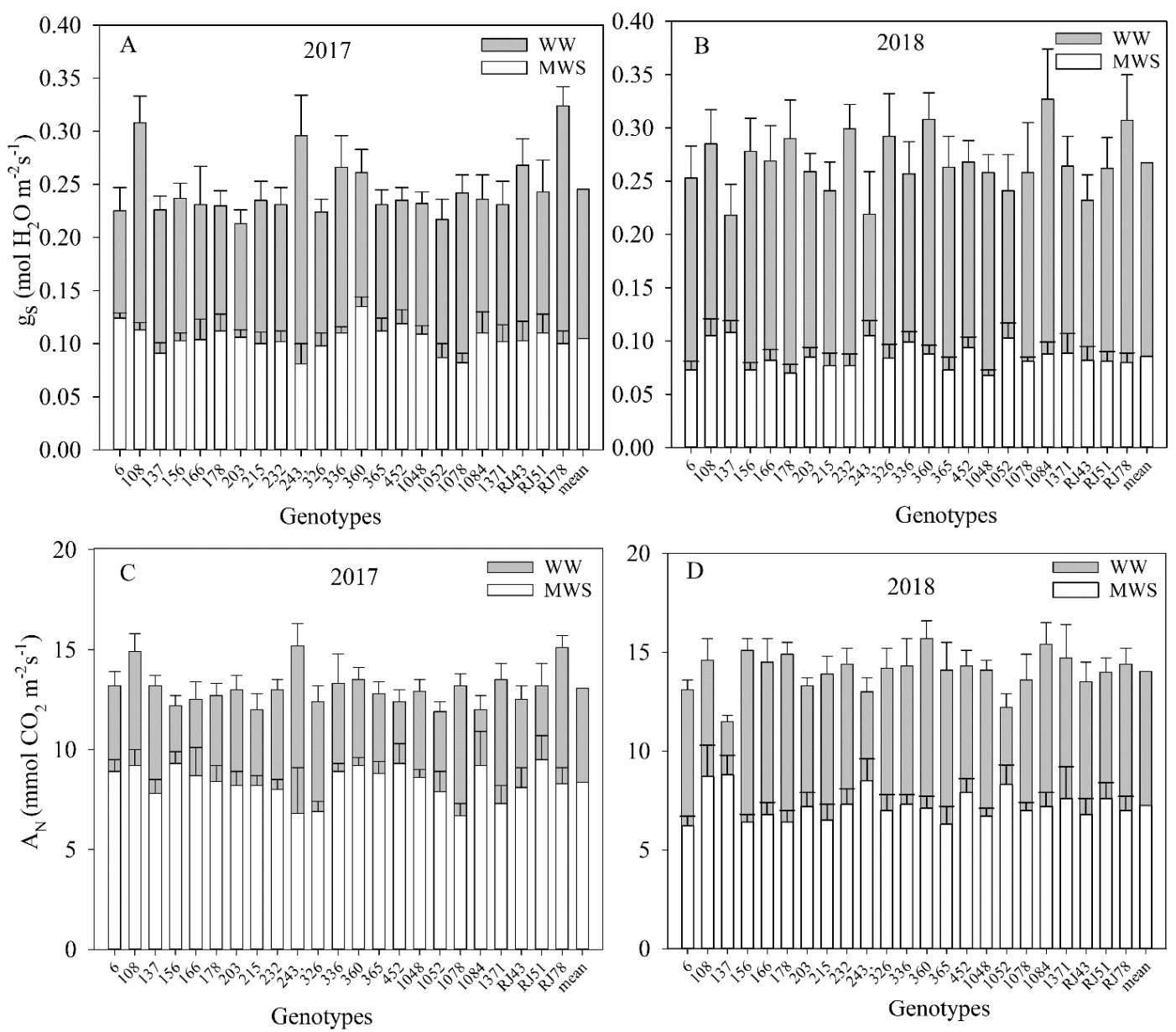

Genotypes
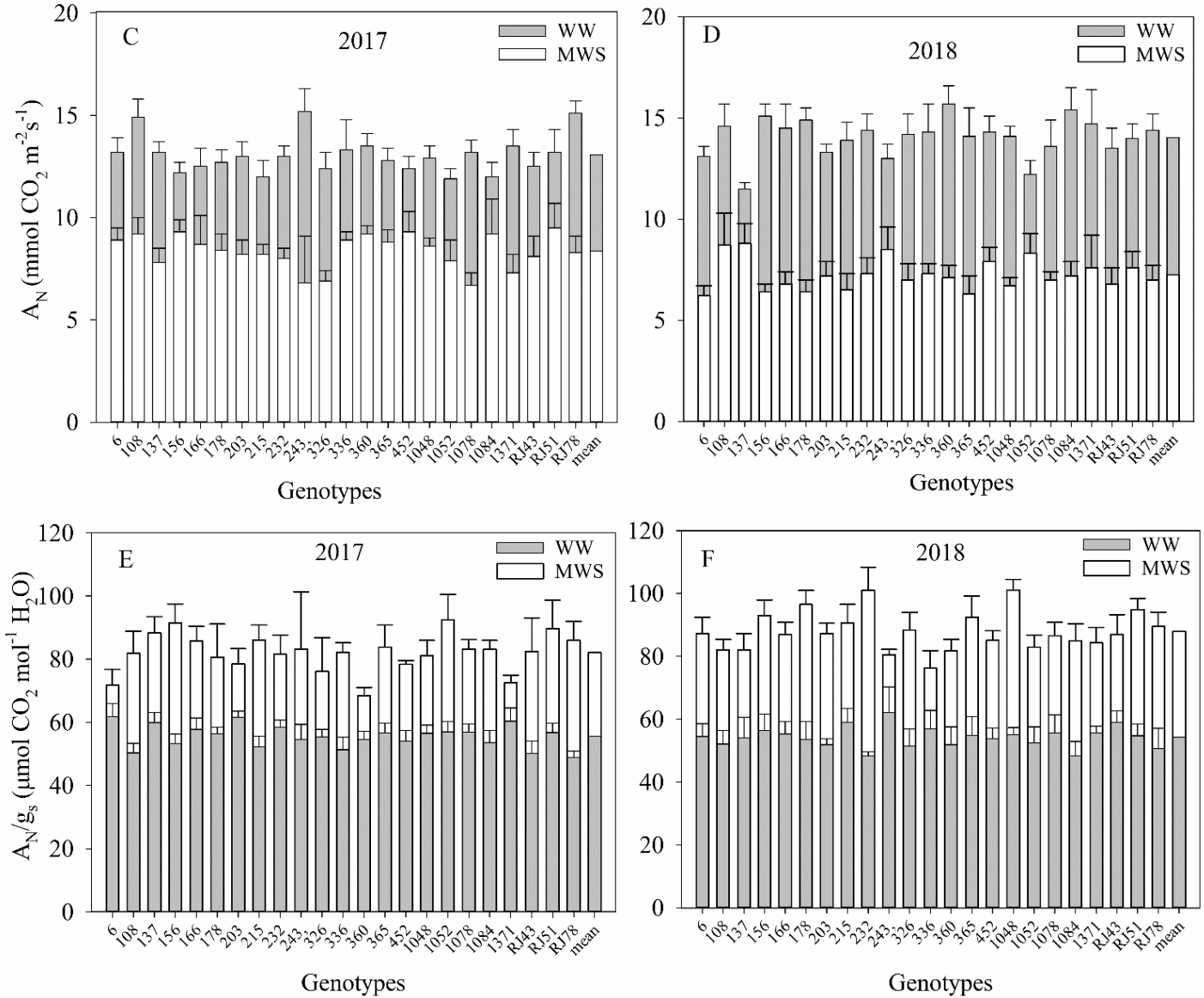

Figure 4. Leaf stomatal conductance $\left(g_{s}\right)$, net photosynthesis rates $\left(A_{N}\right)$ and intrinsic water use efficiency $\left(W_{U} E_{i}\right)$ for each genotype measured in 2017 (A,C,E) and $2018(\mathbf{B}, \mathbf{D}, \mathbf{F})$ in well-watered (WW) (grey bars) and moderate water stress (MWS) (white bars) s. Values are the mean \pm SE $(n=5)$. 
A three-way ANOVA (Year $\times$ irrigation treatment $\times$ Genotype) showed that irrigation treatment and Genotype effects were statistically significant for $A_{N}, g_{s}$, and $W E_{i}$. The Year effect was significant only for $\mathrm{WUE}_{\mathrm{i}}$ (Table 2).

As reported before, the relationship between $W_{U} E_{i}$ and $g_{s}$ was strongly significant. In consequence, to overcome the $W_{U E}$ variability induced by the range of variation of $g_{s}$ during measurements, each genotype was characterized following its residuals of a general $\mathrm{WUE}_{\mathrm{i}}-\mathrm{g}_{\mathrm{s}}$ relationship (Supplementary Figure S1), in terms of percentage $[27,28]$. This presents the advantage of characterize each genotype in respect to the general dependency of $W \mathrm{WE}_{\mathrm{i}}$ over $\mathrm{g}_{\mathrm{s}}$.

The Figure 5 synthetizes the differences in residuals between genotypes. In this way, it was feasible to distinguish four different types of behavior: High and low $W_{U E}$ in both WW and MWS, and its combinations (WW+/MWS- and WW+/MWS-). Interestingly, there was no general relationship between the performance of genotypes in WW against MWS conditions but also some genotype shows better $\mathrm{WUE}_{\mathrm{i}}$ under both conditions. The total variability found was about $15 \%$ in WW condition, with genotypes 243 and 1052 showing the most extreme values ( -7 and $+8 \%$, respectively). In MWS condition, the total variability found was similar to WW condition, with genotype 156 as the most efficient $(+6 \%)$ compared to genotype $360(-8 \%)$ (Figure 5$)$.

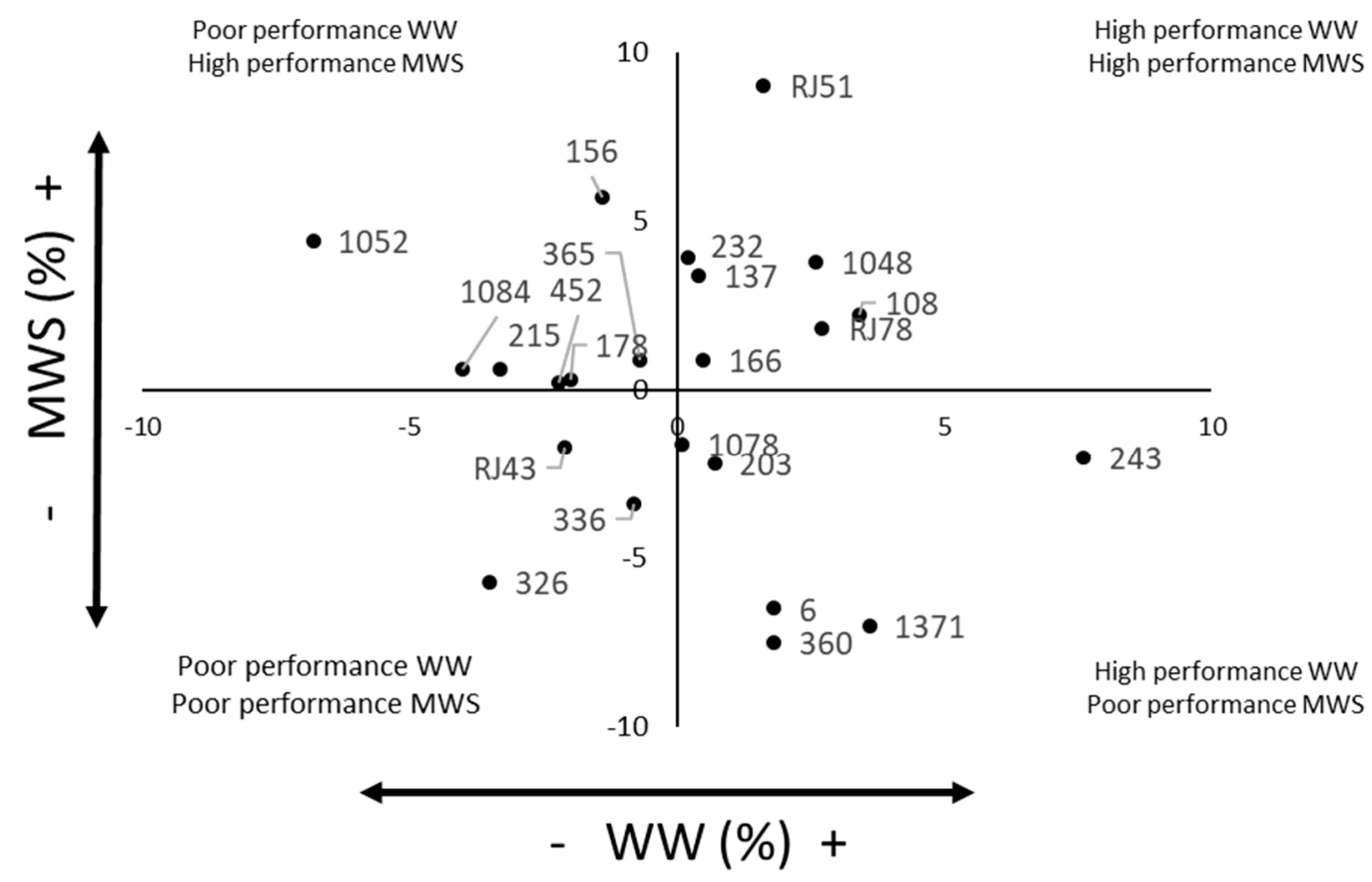

Figure 5. Residuals of the general $W U E_{i}$ over $g_{s}$ model expressed in terms of percentage for every genotype in WW (axis X) and MWS (axis $Y$ ) (See M\&M section). Values are the mean $(n=10)$ of the two experimental years.

Using the $\mathrm{WUE}_{\mathrm{i}}$ and $\mathrm{g}_{\mathrm{s}}$ data generated during 2017 and 2018 for each genotype, we performed a particular lineal model to predict the resultant $W_{U E}$ as a function of $g_{s}$. Introducing the natural logarithm to this relationship allows the linearization of the relationship between the two variables. This model showed a wide variability for the particular genotype slopes, ranging from -3.2 for genotype 156 to -2.0 to genotype 243 (Figure 6; Supplementary Table S1).

The predicted $W \mathrm{WE}_{\mathrm{i}}$ values for every genotype were obtained and ranked for a large range of $\mathrm{g}_{\mathrm{s}}$, from water stress to no water limitations (Table 3). Similar to general trend residuals, three different behaviors were observed: First, some genotypes performed always as highly efficient in the whole range of $g_{s}$, like genotypes 232 or RJ51. Secondly, others are always less efficient, like 326 or RJ43. Thirdly, some genotypes present a clear trade-off along the whole range of $g_{s}$ : the highly efficient at low $\mathrm{g}_{\mathrm{s}}$ and lowly efficient at high $\mathrm{g}_{\mathrm{s}}$ (as 1048 genotype), or inversely, like108. 


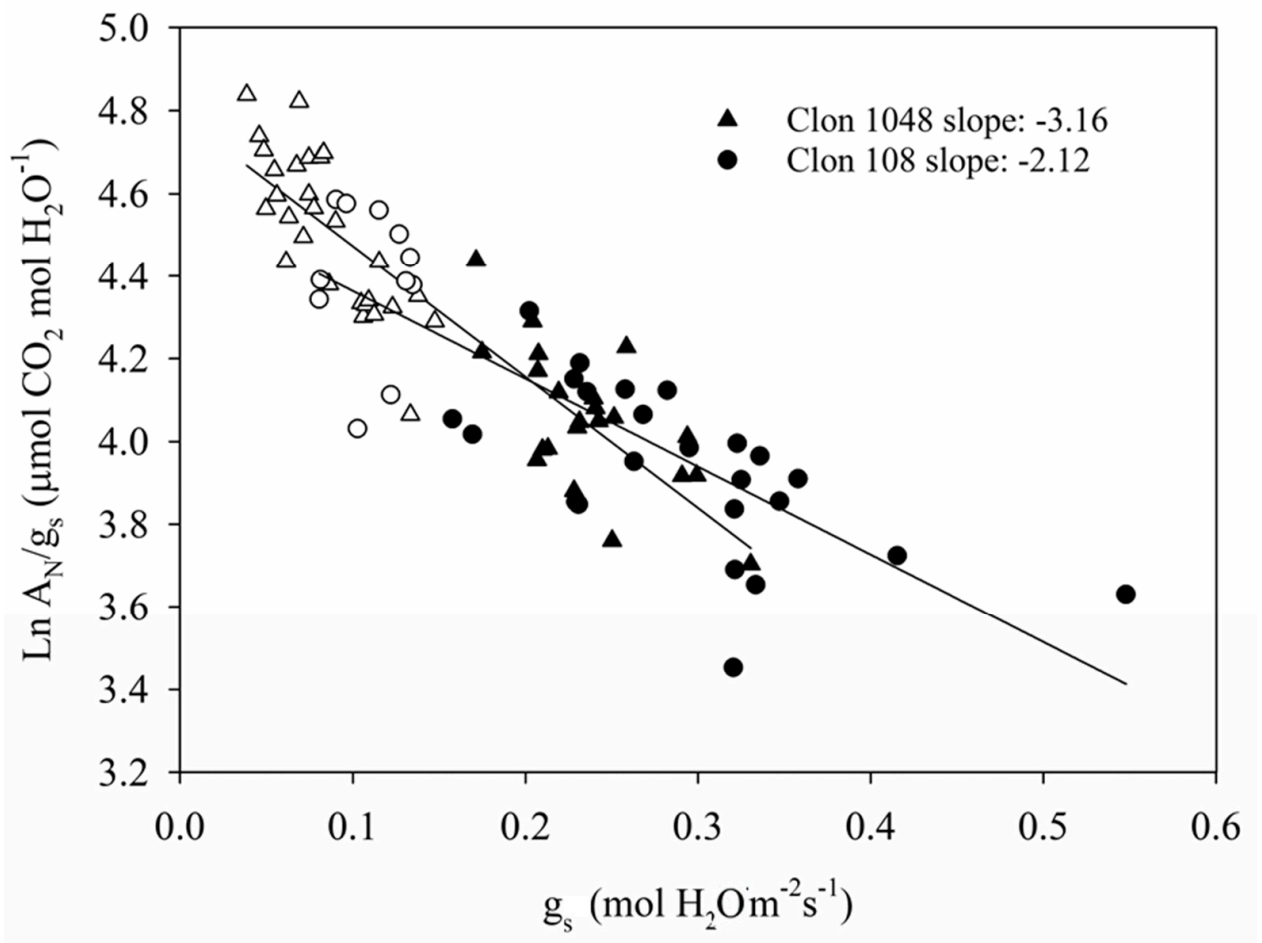

Figure 6. An example of the relationship linearized regressions between $W_{U E}$ and $g_{s}$ using the natural logarithm of WUEi of two contrasting clones. Filled symbols correspond to well-watered conditions; empty symbols correspond to moderate water stress conditions.

Table 3. The relative position of $\mathrm{WUE}_{\mathrm{i}}$ predicted for each genotype linear regression at different $\mathrm{g}_{\mathrm{s}}$ The maximal, minimal, and the mean value of all genotypes were including in $\mu$ mol $\mathrm{CO}_{2} \mathrm{~mol}^{-1} \mathrm{H}_{2} \mathrm{O}$.

\begin{tabular}{|c|c|c|c|c|c|c|c|}
\hline \multirow[b]{2}{*}{ Genotype } & \multicolumn{7}{|c|}{$\stackrel{\mathrm{g}_{\mathrm{s}}}{\left(\mathrm{mol} \mathrm{H} \mathrm{O}_{\mathrm{m}^{-2}} \mathrm{~s}^{-1}\right)}$} \\
\hline & 0.075 & 0.100 & 0.150 & 0.200 & 0.250 & 0.300 & 0.350 \\
\hline 6 & 17 & 17 & 16 & 13 & 12 & 11 & 11 \\
\hline 108 & 19 & 19 & 10 & 6 & 6 & 4 & 4 \\
\hline 137 & 5 & 5 & 8 & 14 & 15 & 16 & 17 \\
\hline 156 & 2 & 2 & 4 & 16 & 20 & 22 & 21 \\
\hline 166 & 13 & 11 & 9 & 3 & 5 & 6 & 6 \\
\hline 178 & 7 & 6 & 6 & 8 & 13 & 13 & 13 \\
\hline 203 & 15 & 14 & 14 & 10 & 8 & 9 & 9 \\
\hline 215 & 11 & 12 & 19 & 20 & 21 & 19 & 18 \\
\hline 232 & 3 & 3 & 3 & 5 & 9 & 12 & 12 \\
\hline 243 & 21 & 20 & 11 & 4 & 2 & 2 & 1 \\
\hline 326 & 20 & 21 & 23 & 21 & 17 & 15 & 15 \\
\hline 336 & 16 & 15 & 15 & 11 & 11 & 10 & 10 \\
\hline 360 & 23 & 23 & 22 & 17 & 7 & 7 & 7 \\
\hline 365 & 4 & 4 & 7 & 15 & 16 & 17 & 19 \\
\hline 452 & 8 & 10 & 12 & 19 & 19 & 18 & 16 \\
\hline 1048 & 1 & 1 & 2 & 9 & 17 & 21 & 22 \\
\hline 1052 & 6 & 7 & 13 & 23 & 23 & 23 & 23 \\
\hline 1078 & 18 & 18 & 17 & 12 & 10 & 8 & 8 \\
\hline 1084 & 14 & 16 & 20 & 18 & 14 & 14 & 13 \\
\hline 1371 & 22 & 22 & 18 & 7 & 4 & 3 & 3 \\
\hline RJ43 & 12 & 13 & 21 & 22 & 22 & 20 & 20 \\
\hline RJ51 & 9 & 8 & 1 & 1 & 1 & 1 & 2 \\
\hline RJ78 & 10 & 9 & 5 & 2 & 3 & 5 & 5 \\
\hline Max & 94.6 & 87.1 & 74.0 & 66.1 & 59.0 & 52.7 & 47.7 \\
\hline Min & 80.7 & 76.6 & 68.8 & 60.3 & 51.3 & 43.7 & 37.2 \\
\hline Mean & 86.8 & 81.3 & 71.3 & 62.6 & 54.9 & 48.3 & 42.4 \\
\hline
\end{tabular}




\section{Discussion}

The improvement of WUE in crops is a widely followed target because water scarcity is a main restriction to a sustainable harvest [32]. For viticulture, this is even more important because more than $60 \%$ of viticulture is located in semi-arid areas [33]. Thus, a great effort is being done to improve the agronomical practices to reduce grape water consume by adjusting irrigation schedule and dosage [34,35] and other agronomic ways [36,37].

Behind such efforts, the identification of grapevine genotypes with enhanced WUE is being explored by different research groups with interesting results; for grapevine cultivars [13,20,38,39]; for rootstock [40-42] and for clones of the same cultivar [27,28,43]

In previous work, we demonstrate the existence of an interesting variability for WUE among Tempranillo clones, as high as $80 \%$ of the observed in a grapevine cultivar collection [27]. After considering the interest to qualify the WUE under realistic field growing conditions that usually corresponds with a wide $g_{s}$ variation among locations and years, field measurements of $\mathrm{WUE}_{\mathrm{i}}$ on in situ collections of Tempranillo genotypes were analyzed with a contrasting regression methodology [28]. This consisted to analyze $\mathrm{WUE}_{\mathrm{i}}$ values on the basis of a calculated residual value of each genotype with respect to the average expected value for certain $\mathrm{g}_{\mathrm{s}}$ inside the general regression curve between $W_{U E}$ and $g_{s}$ [43]. In spite of the similar climatic conditions between locations, the wide environmental variation related to soil conditions, plant health or microbiological status forces to study the clones behavior under more controlled conditions. Therefore, the present work was undertaken to measure under similar climatic and edaphic conditions (pots) such clone WUE, introducing some assessment on the plant growth and biomass production as putative targets to identify extreme genotypes.

The growth parameters and final above-ground production were widely variable. SGR and LAR provide a short-time sensibility to water availability. In our experimental conditions, SGR was more sensible to moderate water stress than LAR and permitted to discriminate better among clones. In general, moderate water stress implied a severe reduction of SGR, but this reduction was very variable depending of the clone, ranging between 25 (clone 336) to 90\% (clone 1078) with respect to well-watered condition. However, there was no correspondence between these parameters and total final biomass. The biomass production ranged between 55 to $110 \mathrm{~g}$ of dry matter and was comparable to other previous experiments [10]. Biomass production was negatively affected by the application of water stress, as expected. We identified genotypes 232 and 326 as highly productive each year, and genotype 1052 as a low productive the two years. Because water availability for each clone was the same, the biomass production should reflect a higher plant WUE.

Leaf gas exchange parameters were in the range of previously reported studies $[10,20]$, and the stomatal conductance in each treatment responded as expected to the proposed levels to evaluate water deficit, according to Medrano et al. (2003). The $\mathrm{WUE}_{\mathrm{i}}$ genotypic variability reached 25 and $20 \%$ under water stress and well-watered conditions, respectively. However, the ANOVA showed statistical significance only for the year and the treatment effects. It is important to note that large differences in $A_{N}$ and $g_{s}$ were observed among genotypes (see Table 2), demonstrating that some genotypes present large fluxes of $\mathrm{CO}_{2}$ and water, and others low gas exchange fluxes. Nevertheless, if the difference of each flux $\left(A_{N}\right.$ and $\left.g_{s}\right)$ between genotypes are proportional, this can provide the same $W_{U E}\left(W U E_{i}=A_{N} / g_{s}\right)$. Moreover, it can be argued that the presence of bunches in the second year affected the plant gas exchange. Indeed, bunches are an important sink of carbon at the plant level [44-47], thus this can strongly affect the gas exchange at the leaf level. The fact the bunches were not present in the first year of study, but the second would increase the year effect, thus decreasing the genotype effect in the three-ways ANOVA.

To compare $W_{U E}$ among genotypes but reducing the $g_{s}$ influence, we used two different approaches: (1) A general $W_{U E}$ over $g_{s}$ relationship was established (all genotypes together) and the residuals of each genotype were calculated to appreciate if a given genotype is above or below the common trend [27]); and (2) a specific $\mathrm{WUE}_{\mathrm{i}}$ over $\mathrm{g}_{\mathrm{s}}$ relationship for each genotype was established 
(Figure 6), that provides the sensibility of each clone to water deficit according to the slope of the linear regression obtained from this relationship, then, lower slope means lower sensible the clone to the water deficit. From these adjustments, we evaluated the relative position of each genotype establishing seven different $g_{s}$ range (from water deficit to well-watered). It is important to note that, in general, the statistical significance is poor for $\mathrm{WUE}_{\mathrm{i}}$, due to the high number of genotypes and the limited number of replicates. However, these previous results report an interesting information about clone's performance.

The Figure 5 synthetizes the differences in the residuals between genotypes. This allows to separate the genotypes following their performance under both well-watered and water deficit conditions. Therefore, it was possible to firstly identify good performance genotypes under both conditions, like 1048 y RJ51. The fact that no genotype is present on the extreme corner of the plane suggests that is it difficult for the same genotype to show very high $W_{U E}$ under both WW and WMS conditions. This would require at once high photosynthesis performance under WW and a strong stomatal control under WMS. Those results were confirmed for RJ51, which showed a high ranking of $\mathrm{WUE}_{\mathrm{i}}$ in both WW and MSW (see Figure 5, confirming that the two evaluation approaches gave the same tendency.

Inversely, some genotypes were identified showing poor $\mathrm{WUE}_{\mathrm{i}}$ under all conditions as genotype 326, showing high $g_{s}$, especially in 2018 (Figure 5). It is so considered as a water spender independently of the conditions and was interestingly in the highest rank in terms of biomass accumulation (Figure 3). This was clearly confirmed using the second approach (Table 3), with genotype 326 being in the latest ranks. This specific behavior can only be interesting in areas where water is not limiting at all.

Some genotypes showed poor $W_{U E}$ performance under WW but good performance under MWS condition, as genotype 1052 (Figure 5). This genotype was also the last ranked using the second approach and in ranks 6-7 under water limited conditions (Table 3). Those are interesting, especially in areas where water is limiting, or in the context of climate change as this paper is focused on. This suggests a low stomatal control (high $\mathrm{g}_{\mathrm{s}}$ ) under WW condition. This corresponds to the principle of the season and actually can be seen as an advantage in agronomy. Indeed, at that time, water is usually available and high $\mathrm{g}_{\mathrm{s}}$ is usually associated with high biomass production. The high WUE performance under water limited conditions suggest a tight stomatal control and fit with the summer when all the leaf area is already established. Those genotypes would be thus capable to establish high leaf area in spring and then have a strong stomatal control when water is not available.

Finally, some opposite behavior was also present, which consists in high and low $\mathrm{WUE}_{\mathrm{i}}$ under WW and WMS conditions, as genotype 1371 (Figure 5). It was also at one of the latest ranked under WMS, and in the top of the rank in WW condition (Table 3). This is characterized by saving water when it is available, and be a water spender when water is limited, presenting poor interest at the physiological point of view (increased risk of cavitation under drought) and also at the agronomic scale. Altogether, these results show a wide scope of water stress responses among clones of the same variety, providing an interesting field to be studied in the future.

Ranking genotypes can be difficult because of the different scales used to estimate WUE $\mathrm{E}_{\mathrm{i}}$. Moreover, scarce information has been published showing relations between plant and leaf scale measured WUE [10]. In this sense, no relationship between scales was found in the present work. Additionally, an important year effect was also present, both at plant and leaf scale, as previously reported for different grapevine experimental conditions [25,48]. Such "year" effect summarized plant/soil/climate conditions and agricultural practices interactions which are commonly observed in commercial viticulture [49]. To Tempranillo clones, we also reported an important year effect on the $W_{U E}$ values in the field evaluation repeated during consecutive campaigns [28].

Interestingly, some of the most productive clones in terms of final biomass were coincident between years, as genotypes 232 and 1048. The less productive ones were less coincident, with some exceptions like genotype 1052. In any case, the plant scaled parameters like WUE or growth, resulted to have also a high plant-to-plant variability, generally reducing the statistical significance. Increase the 
number of replicates and more years of experiments can help to definitively confirm those interesting results in terms of plant production and WUE.

Based on the results, the identifications of higher/lower WUE genotypes can be established. On one hand, considering the biomass and growth parameters, genotypes 232, 1048, and 326 tended to show good performance compared to genotypes 1052 or 6 . On the other hand, considering directly photosynthetic $W U E_{i}$, results were not conserved between years. Using predicting models, the 232 and RJ51 genotypes were the most efficient, contrary to those observed in 1052 and RJ43. Considering plant and leaf parameters at the same time, the genotypes 232 and 1052 could be the most contrasting genotypes in terms of biomass and leaf water use efficiency.

Supplementary Materials: The following are available online at http://www.mdpi.com/2073-4395/10/6/862/s1, Figure S1: General relationship between $W_{U E}$ and $g_{s}$ in 2017 (A) and 2018 (B). Filled symbols indicate well-watered plants; empty symbols indicate moderate water stressed plants., Table S1: Intercepts (a), slopes (b), correlation coefficient $\left(R^{2}\right)$ and number of data $(n)$ of the logarithmic relation between $g_{s}$ and WUE $\left(L N\left(W U E_{i}\right)=a+b\left(g_{s}\right)\right)$ for ach genotype.

Author Contributions: Data curation, I.T., C.D. and G.T.; formal analysis, I.T., C.D., G.T.; funding acquisition, J.M.E. and H.M.; methodology, J.M.E. and H.M.; project administration, J.M.E.; writing-original draft, I.T., J.M.E. and H.M.; writing-review and editing, I.T., J.M.E. and H.M. All authors have read and agreed to the published version of the manuscript.

Funding: This work was performed with the financial support from the Spanish Ministry of Science and Technology (project AGL2014-54201-C4-1-R and AGL2017-83738-C3-1-R) and a pre-doctoral fellowship BES-2015-073331.

Acknowledgments: The authors would like to thank Miquel Truyols and collaborator of the UIB experimental Field (UIB Grant 15/2015) for their support to our experiments. We also want to thank the collaboration of Instituto de las Ciencias y el Vino (ICVV), Bodegas Roda S.A and Viveros Provedo S.A. to provide us the plant material.

Conflicts of Interest: The funders had no role in the design of the study; in the collection, analyses, or interpretation of data; in the writing of the manuscript, or in the decision to publish the results.

\section{References}

1. Van Leeuwen, C.; Darriet, P. The impact of climate change on viticulture and wine quality. J. Wine Econ. 2016, 11, 150-167. [CrossRef]

2. Fraga, H.; Malheiro, A.C.; Moutinho-Pereira, J.; Santos, J.A. Future scenarios for viticultural zoning in Europe: Ensemble projections and uncertainties. Int. J. Biometeorol. 2013, 57, 909-925. [CrossRef] [PubMed]

3. Vivin, P.; Lebon, É.; Dai, Z.; Duchêne, E.; Marguerit, E.; de Cortázar-Atauri, I.G.; Ollat, N. Combining ecophysiological models and genetic analysis: A promising way to dissect complex adaptive traits in grapevine. OENO One 2017, 51, 181-189. [CrossRef]

4. Medrano, H.; Tortosa, I.; Montes, E.; Pou, A.; Balda, P.; Bota, J.; Escalona, J.M. Genetic improvement of grapevine (Vitis vinifera L.) water use efficiency: Variability among varieties and clones. In Water Scarcity and Sustainable Agriculture in Semiarid Environment; García-Tejero, I.F., Duran, V.H.I., Eds.; Academic Press: London, UK, 2018; pp. 377-401.

5. Laucou, V.; Launay, A.; Bacilieri, R.; Lacombe, T.; Adam-Blondon, A.F.; Berard, A.; Ibañez, J.; Le Paslier, M.C. Extended diversity analysis of cultivated grapevine Vitis vinifera with $10 \mathrm{~K}$ genome-wide SNPs. PLoS ONE 2018, 13, e0192540. [CrossRef] [PubMed]

6. Ibáñez, J.; Carreño, J.; Yuste, J.; Martínez-Zapater, J.M. Grapevine breeding and clonal selection programmes in Spain. In Grapevine Breeding Programs for the Wine Industry; Reynolds, A., Ed.; Woodhead Publishing: Cambridge, UK, 2015; pp. 183-209.

7. Flexas, J.; Galmés, J.; Gallé, A.; Gulías, J.; Pou, A.; Ribas-Carbo, M.; Tomás, M.; Medrano, H. Improving water use efficiency in grapevines: Potential physiological targets for biotechnological improvement. Aust. J. Grape Wine Res. 2010, 16, 106-121. [CrossRef]

8. Bchir, A.; Escalona, J.M.; Gallé, A.; Hernández-Montes, E.; Tortosa, I.; Braham, M.; Medrano, H. Carbon isotope discrimination $(\delta 13 \mathrm{C})$ as an indicator of vine water status and water use efficiency (WUE): Looking for the most representative sample and sampling time. Agric. Water Manag. 2010, 167, 11-20. [CrossRef] 
9. Santesteban, L.G.; Miranda, C.; Urretavizcaya, I.; Royo, J.B. Carbon isotope ratio of whole berries as an estimator of plant water status in grapevine (Vitis vinifera L.) cv. 'Tempranillo'. Sci. Hortic. 2012, 146, 7-13. [CrossRef]

10. Tomás, M.; Medrano, H.; Escalona, J.M.; Martorell, S.; Pou, A.; Ribas-Carbó, M.; Flexas, J. Variability of water use efficiency in grapevines. Environ. Exp. Bot. 2014, 103, 148-157. [CrossRef]

11. Escalona, J.M.; Tomàs, M.; Martorell, S.; Medrano, H.; Ribas-Carbo, M.; Flexas, J. Carbon balance in grapevines under different soil water supply: Importance of whole plant respiration. Aust. J. Grape Wine Res. 2012, 18, 308-318. [CrossRef]

12. Medrano, H.; Tomás, M.; Martorell, S.; Flexas, J.; Hernández, E.; Rosselló, J.; Pou, A.; Escalona, J.M.; Bota, J. From leaf to whole-plant water use efficiency (WUE) in complex canopies: Limitations of leaf WUE as a selection target. Crop. J. 2015, 3, 220-228. [CrossRef]

13. Coupel-Ledru, A.; Lebon, E.; Christophe, A.; Gallo, A.; Gago, P.; Pantin, F.; Doligez, A.; Simonneau, T. Reduced nighttime transpiration is a relevant breeding target for high water-use efficiency in grapevine. Proc. Natl. Acad. Sci. 2016, 113, 8963-8968. [CrossRef] [PubMed]

14. Flexas, J.; Bota, J.; Escalona, J.M.; Sampol, B.; Medrano, H. Effects of drought on photosynthesis in grapevines under field conditions: An evaluation of stomatal and mesophyll limitations. Funct. Plant. Biol. 2002, 29, 461-471. [CrossRef]

15. Medrano, H.; Escalona, J.M.; Bota, J.; Gulías, J.; Flexas, J. Regulation of photosynthesis of C3 plants in response to progressive drought: Stomatal conductance as a reference parameter. Ann. Bot. 2002, 89, 895-905. [CrossRef] [PubMed]

16. Merli, M.C.; Gatti, M.; Galbignani, M.; Bernizzoni, F.; Magnanini, E.; Poni, S. Water use efficiency in Sangiovese grapes (Vitis vinifera L.) subjected to water stress before veraison: Different levels of assessment lead to different conclusions. Funct. Plant. Biol. 2015, 42, 198-208. [CrossRef]

17. Bota, J.; Flexas, J.; Medrano, H. Genetic variability of photosynthesis and water use in Balearic grapevine cultivars. Ann. Appl. Biol. 2001, 138, 353-361. [CrossRef]

18. Tomás, M.; Medrano, H.; Pou, A.; Escalona, J.M.; Martorell, S.; Ribas-Carbó, M.; Flexas, J. Water-use efficiency in grapevine cultivars grown under controlled conditions: Effects of water stress at the leaf and whole-plant level. Aust. J. Grape Wine Res. 2012, 18, 164-172. [CrossRef]

19. Costa, J.M.; Ortuño, M.F.; Lopes, C.M.; Chaves, M.M. Grapevine varieties exhibiting differences in stomatal response to water deficit. Funct. Plant. Biol. 2012, 39, 179-189. [CrossRef]

20. Bota, J.; Tomás, M.; Flexas, J.; Medrano, H.; Escalona, J.M. Differences among grapevine cultivars in their stomatal behavior and water use efficiency under progressive water stress. Agric. Water Manag. 2016, 164, 91-99. [CrossRef]

21. Morales, F.; Ancín, M.; Fakhet, D.; González-Torralba, J.; Gámez, A.L.; Seminario, A.; Soba, D.; Ben Mariem, S.; Garriga, M.; Aranjuelo, I. Photosynthetic Metabolism under Stressful Growth Conditions as a Bases for Crop Breeding and Yield Improvement. Plants 2020, 9, 88. [CrossRef]

22. Rühl, E.; Konrad, H.; Lindner, B.; Bleser, E. Quality criteria and targets for clonal selection in grapevine. Acta Hortic. 2004, 652, 29-33. [CrossRef]

23. Hajdu, E.; Korac, N.; Cindric, P.; Ivanisevic, D.; Medic, M. The importance of clonal selection of grapevine and the role of selected clones in production of healthy propagating stocks. Int. J. Hortic. Sci. 2011, 17, 15-24. [CrossRef]

24. Arrizabalaga, M.; Morales, F.; Oyarzun, M.; Delrot, S.; Gomès, E.; Irigoyen, J.J.; Hilbert, G.; Pascual, I. Tempranillo clones differ in the response of berry sugar and anthocyanin accumulation to elevated temperature. Plant Sci. 2018, 267, 74-83. [CrossRef] [PubMed]

25. Cervera, M.T.; Cabezas, J.A.; Rodríguez-Torres, I.; Chavez, J.; Cabello, F.; Martínez-Zamboni, M.; Garavani, A.; Gatti, M.; Vercesi, A.; Parisi, M.G.; et al. Vegetative, physiological and nutritional behavior of new grapevine rootstocks in response to different nitrogen supply. Sci. Hortic. 2016, 202, 99-106.

26. Grimplet, J.; Ibáñez, S.; Baroja, E.; Tello, J.; Ibáñez, J. Phenotypic, hormonal, and genomic variation among Vitis vinifera clones with different cluster compactness and reproductive performance. Front. Plant Sci. 2019, 9, 1917. [CrossRef] [PubMed]

27. Tortosa, I.; Escalona, J.M.; Bota, J.; Tomas, M.; Hernandez, E.; Escudero, E.G.; Medrano, H. Exploring the genetic variability in water use efficiency: Evaluation of inter and intra cultivar genetic diversity in grapevines. Plant Sci. 2016, 251, 35-43. [CrossRef] 
28. Tortosa, I.; Douthe, C.; Pou, A.; Balda, P.; Hernandez-Montes, E.; Toro, G.; Escalona, J.M.; Medrano, H. Variability in water use efficiency of grapevine Tempranillo clones and stability over years at field conditions. Agronomy 2019, 9, 701. [CrossRef]

29. Team, R.C. A Language and Environment for Statistical Computing; R Foundation for Statistical Computing: Vienna, Austria, 2014.

30. Fox, J.; Weisberg, S. Multivariate linear models in R. In An $R$ Companion to Applied Regression; SAGE Publications, Inc.: Los Angeles, CA, USA; Thousand Oaks, CA, USA, 2011.

31. Lenth, R.; Lenth, M.R. Package 'lsmeans'. Am. Stat. 2018, 34, 216-221.

32. Ollat, N.; Van Leeuwen, C.; de Cortazar-Atauri, I.G.; Touzard, J.M. The challenging issue of climate change for sustainable grape and wine production. Int. J. Vine Wine Sci. 2017, 51, 59-60.

33. Costa, J.M.; Vaz, M.; Escalona, J.; Egipto, R.; Lopes, C.; Medrano, H.; Chaves, M.M. Modern viticulture in southern Europe: Vulnerabilities and strategies for adaptation to water scarcity. Agric. Water Manag. 2016, 164, 5-18. [CrossRef]

34. Uriarte, D.; Intrigliolo, D.S.; Mancha, L.A.; Picón-Toro, J.; Valdes, E.; Prieto, M.H. Interactive effects of irrigation and crop level on Tempranillo vines in a semiarid climate. Am. J. Enol. Vitic. 2015, 66, 101-111. [CrossRef]

35. Romero, P.; Pérez-Pérez, J.G.; del Amor, F.M.; Martinez-Cutillas, A.; Dodd, I.C.; Botía, P. Partial root zone drying exerts different physiological responses on field-grown grapevine (Vitis vinifera cv. Monastrell) in comparison to regulated deficit irrigation. Funct. Plant Biol. 2014, 41, 1087-1106. [CrossRef]

36. de Oliveira, A.F.; Nieddu, G. Deficit irrigation strategies in Vitis vinifera L. cv. Cannonau under Mediterranean climate. Part II-cluster microclimate and anthocyanin accumulation patterns. S. Afr. J. Enol. Vitic. 2013, 34, 184-195. [CrossRef]

37. Medrano, H.; Tomás, M.; Martorell, S.; Escalona, J.M.; Pou, A.; Fuentes, S.; Flexas, J.; Bota, J. Improving water use efficiency of vineyards in semi-arid regions. A review. Agron. Sustain. Dev. 2015, 35, 499-517. [CrossRef]

38. Prieto, J.A.; Lebon, É.; Ojeda, H. Stomatal behavior of different grapevine cultivars in response to soil water status and air water vapor pressure deficit. OENO One 2010, 44, 9-20. [CrossRef]

39. Escalona, J.M.; Tomàs, M.; Ribas-Carbo, M.; Medrano, H.; Bota, J. Genetic variation of plant water status, water use efficiency and grape yield and quality in response to soil water availability in grapevine (Vitis vinifera L.). In Proceedings of the 28th International Horticultural Congress Lisbon, Lisbon, Portugal, 22-27 August 2010; pp. 143-150.

40. Galbignani, M.; Merli, M.C.; Magnanini, E.; Bernizzoni, F.; Talaverano, I.; Gatti, M.; Pallioti, A.; Poni, S. Gas exchange and water-use efficiency of $\mathrm{cv}$. Sangiovese grafted to rootstocks of varying water-deficit tolerance. Irrig. Sci. 2016, 34, 105-116. [CrossRef]

41. Zhang, L.; Marguerit, E.; Rossdeutsch, L.; Ollat, N.; Gambetta, G.A. The influence of grapevine rootstocks on scion growth and drought resistance. Exp. Plant Physiol. 2016, 28, 143-157. [CrossRef]

42. Romero, P.; Botía, P.; Navarro, J.M. Selecting rootstocks to improve vine performance and vineyard sustainability in deficit irrigated Monastrell grapevines under semiarid conditions. Agric. Water Manag. 2018, 209, 73-93. [CrossRef]

43. Tortosa, I.; Escalona, J.M.; Douthe, C.; Pou, A.; Garcia-Escudero, E.; Toro, G.; Medrano, H. The intra-cultivar variability on water use efficiency at different water status as a target selection in grapevine: Influence of ambient and genotype. Agric. Water Manag. 2019, 223, 105648. [CrossRef]

44. Koblet, W.; Keller, M.; Carmo Candolfi-Vasconcelos, M. Effects of training system, canopy management practices, crop load and rootstock on grapevine photosynthesis. Act. Hort. 1997, 427, 133-140. [CrossRef]

45. Morinaga, K.; Imai, S.; Yakushiji, H.; Koshita, Y. Effects of fruit load on partitioning of $15 \mathrm{~N}$ and 13C, respiration, and growth of grapevine roots at different fruit stages. Sci. Hortic. 2003, 97, 239-253. [CrossRef]

46. Petrie, P.R.; Trought, M.T.; Howell, G.S. Influence of leaf ageing, leaf area and crop load on photosynthesis, stomatal conductance and senescence of grapevine (Vitis vinifera L. cv. Pinot noir) leaves. Vitis 2000, 39, 31-36.

47. Vaillant-Gaveau, N.; Wojnarowiez, G.; Petit, A.N.; Jacquens, L.; Panigai, L.; Clement, C.; Fontaine, F. Relationships between carbohydrates and reproductive development in Chardonnay grapevine: Impact of defoliation and fruit removal treatments during four successive growing seasons. OENO One 2014, 48, 219-229. [CrossRef] 
48. Intrigliolo, D.S.; Castel, J.R. Interactive effects of deficit irrigation and shoot and cluster thinning on grapevine cv. Tempranillo. Water relations, vine performance and berry and wine composition. Irrig. Sci. 2011, 29, 443-454. [CrossRef]

49. Petrie, P. Quantifying the advancement and compression of vintage. AWRI 2016, 220, 9-11.

(C) 2020 by the authors. Licensee MDPI, Basel, Switzerland. This article is an open access article distributed under the terms and conditions of the Creative Commons Attribution (CC BY) license (http://creativecommons.org/licenses/by/4.0/). 